\begin{tabular}{|c|c|}
\hline \multirow{4}{*}{ Sosyoloffle Dugalin } & $\begin{array}{c}\text { SOSYOLOJIK DÜŞÜN } \\
\text { e-ISSN: 2587-2699 }\end{array}$ \\
\hline & Haziran 2021 \\
\hline & Yayına Kabul Tarihi: 30.06.2021 \\
\hline & $\begin{array}{c}\text { DOI Numarası: https://doi.org/10.37991/sosdus.931696 } \\
\text { Orcid: 0000-0002-7384-0997 }\end{array}$ \\
\hline
\end{tabular}

\title{
AKADEMISYENLERIN "SERBEST ZAMAN YOKSUNLUĞUNA” ETKI EDEN UNSURLAR: DÜZCE ÜNIVERSITESI ÖRNEĞi
}

\author{
Metin KILIÇ*
}

\begin{abstract}
Öz
Serbest zaman ihtiyacı gündelik yaşamda her geçen gün etkisini artırırken insanlar bu denli önemli bir zamanı elde ettiklerinde anlamlandırmakta güçlükler çekmektedirler. Ekonomik, kültürel ve sosyal sermayelerin yoğun etkisine maruz kalan günümüz insanının en zor elde edip en kolay vazgeçebileceği zaman da kuşkusuz serbest zamandır. Bu açıdan çoğu çalışma serbest zaman kazanımlarından bahsederken, bu çalışmada madalyonun diğer tarafından bakarak serbest zaman yoksunluğunun nasıl üretildiği sosyal sınıf bağlamında anlamlandırılmaya çalışımıştır.

Araştırma nicel araştırma yöntemine göre üniversitede çalışan 422 akademisyen üzerinden geliştirilmiştir. Elde edilen veriler ışığında serbest zaman değerlendirme pratiklerinin statüye göre teşekkül ettiği ve daha çok kariyer planlaması bağlamında serbest zaman etkinliklerine yönelim olduğu görülmüştür. Akademik camia için kariyer planlaması serbest zamanın sınırlarını ortadan kaldıran ve serbest zaman yoksunluğuna neden olan bir olgu olarak ortaya çıkmaktadır.
\end{abstract}

Anahtar Kelimeler: Serbest zaman, Boş zaman, Rekreasyon, Statü, Kariyer

Doç. Dr., Düzce Üniversitesi, Fen-Edebiyat Fakültesi, Sosyoloji Bölümü, metinkilic@duzce.edu.tr 


\title{
FACTORS AFFECTING ACADEMICS" "LEISURE TIME DEPRIVATION": THE CASE OF DÜZCE UNIVERSITY
}

\begin{abstract}
While the need for leisure time increases its impact in daily life, people have difficulties in making sense of such an important time. Undoubtedly, leisure is the time that can most difficult be obtained but easily abandoned by today's people exposed to the intense influence of economic, cultural, and social capitals. In this respect, while most studies focus on leisure time gains, in this study, the attempt is to make sense of how leisure time deprivation is produced in the context of social class by looking at the other side of the coin. Quantitative research was conducted with 422 academics working at the university. In the light of the data obtained, it could be seen that leisure time activities are formed according to status, and there is a tendency to leisure activities in career planning. Thus, career planning emerges as a phenomenon that removes leisure time boundaries for the academic community and leads to leisure time deprivation.
\end{abstract}

Keywords: Leisure, Free time, Recreation, Status, Career

\section{Giriş}

Toplumların dinamik yönüne karşılık gelen niteliğinden ötürü, birçok bilim dalının araştırma konusu olan serbest zaman, o kadar çok farklı biçimlerde çalışılıp incelenmiştir ki, gerçekten de insan onun kadar üzerine yazılıp çizilen başka bir konu olup olmadığından şüphe etmektedir (Öztürk, 2019). Yapılan araştırmalarda, çalışma/iş zamanı her daim sosyal sınıf, cinsiyet, yaş gibi değişkenlere bağlı olarak önemini korumuştur. Çalışma zamanının karşısında yer alan boş zamanın içerisinde var olan serbest zaman; kimi zaman işe hazırlayan, kimi zaman çalışmaktan üstün olan, kimi zaman insanı tembelleştiren, kimi zamanda kapitalist üretime hizmet eden bir zaman olarak yeniden üretilmiştir. Günümüzde ise kurumsal bir yapıya bürünen serbest zamanı insanın kendisini yenilemesine ve yaşam kalitesini arttırmasına imkân tanıyan "değerli zaman" olarak kavramsallaştırmak mümkündür. Değerli zaman olarak atfettiğimiz serbest zamanın boş zamandan farklı ve boş zaman içerisinde kendisini üreten bir üçüncü zaman olduğunu gözden kaçırmamak gerekir (Kılıç, 2020). 
Bu üçüncü zamanın sosyolojik bağlamda üretimi kadar tüketimi de günümüzde önemlidir. Makro seviyede serbest zaman toplumunun olabilirliği tartışılırken mikro seviyede de aktörlerin hiç bugün ki kadar serbest zaman ihtiyacı doğmamıştır. Çalışmak kadar hayati öneme sahip olan serbest zaman modernleşmeye bağlı olarak kendini yeniden üretirken serbest zaman yoksunluğu da kendini yeniden üretmektedir. Serbest zaman yoksunluğu, serbest zamanın tüketimi ile doğrudan ilişkilidir. Yaşam tarzını tüketimle özdeşleştiren Paterson'ın (2006), Tüketim ve Gündelik Hayat kitabında, tüketimin insanın kendini ifade etmesi olarak görmesi de serbest zaman tüketiminin soyut bir göstergesidir. Serbest zaman tüketimi bu anlamda kültürel bir tüketime dönüşürken, bireylerin statülerine göre değerlendirilmesi gerekir. Serbest zaman ve statü ilişkisi incelendiğinde, sosyoloji literatüründe statü özellikle tabakalaşma tartışmalarında sınıf kavramı ile karşılıklı olarak ele alınır (Olgun, 2019). Bauman'a (2012) göre; üst sınıfa mensup insanları gelecekleri kadar geçmişlerinden de tamamen yalıtılmış olan ve birbiri ardına sıralanan anların içinden geçerek, daimi bir şimdi de yaşarlar. Bu insanlar hep meşguldür. Daima "zaman darlığı" çekerler; çünkü zamanın her bir anı, uzantısı olmayan bir parçadır. Bu ağzına kadar dolu zaman deneyimine özdeş bir deneyimdir. Karşı dünyanın (alt sınıfın) kara kara düşünen umutsuz insanları ise bol, gereksiz, boş ve içini dolduracak hiçbir şeye sahip olmadıkları zamanın yükü altında ezilirler. Onların zamanında, hiçbir şey olmaz. Onlar zamanı kontrol etmezler. Zaman onları yavaş yavaş öldürürken, yapabilecekleri tek şey zaman öldürmektir. Yine benzer argümanı savunan Bourdieu'ya (2016) göre de; zamanlarının bir değeri olmadığı için mülkleri eksik, zamanları fazla olan-proleterlerin aksine, işkolik yöneticilerin mülkleri fazla, zamanlarıysa olağanüstü eksiktir. Csikszentmihalyi'e (2018) göre de zor elde edilen serbest zamanlarından zevk almaları gerekirken insanlar genelde şaşırtıcı derecede kötü bir ruh halinde olduklarını söylerler; ama daha fazla serbest zaman istemeye devam ederler. Sınıfsal olarak ortaya 
konulan serbest zaman kullanımı farklı sınıfların serbest zaman yoksunluğunu net bir şekilde göstermektedir. Toplumsal sınıf ayrımları gözetildiğinde çalışmaktan yoksun olan ve çok çalışan insanların serbest zamanının az ya da çok olması serbest zaman yoksunluğunu farklılaştırmamaktadır. Bauman ve Bourdieu'nun çözümlemelerinden hareketle sınıf ve serbest zaman ilişkisi makro düzeyde ifade edilirken, statü bağlamında serbest zaman yoksunluğunun nasıl bir kültürel tüketim nesnesine dönüştüğünü görmek mümkündür. $O$ halde serbest zaman yoksunluğu nedir? diye sormak gereklidir. Kılıç'ın (2019) yazdığı "Leisure Time Deprivation" adlı makalede serbest zaman yoksunluğunun kuramsal temelleri net bir şekilde ifade edilmiştir. Ona göre, "Serbest zaman yoksunluğu; insanların serbest zaman aktivitelerine katılacak zamanının olmaması, sosyo-kültürel sermayesinin yetersiz olması ya da serbest zamanı olmasına rağmen bu zamanı nasıl kullanacağını bilememesi/kullanamamasıdır".

Değerli olarak atfettiğimiz böyle bir zamanın yoksunluğunun temelleri sorgulandığında, kişilerin doğuştan gelen statü ölçütleriyle (yaş, cinsiyet, soybağı-sosyal çevre) sonradan kazanılan statü ölçütleri (eğitim, meslek, servet) arasındaki ilişkiye bakmak gerekir. Bu ölçütler esasında serbest zaman yoksunluğunu modern toplumda yeniden üretir. Serbest zamanın varlığının kültürel tecrübelere dayandığını öne süren MacCannell’in (1999) düşüncesinden hareketle, kişilerin kültürel hedeflere ulaşmak için kurumsal araçları kullanma çabası içerisine girmesi, yani kariyer planlama süreci serbest zaman yoksunluğunu günümüzde oldukça arttırmaktadır.

Yüksek bir seviyede uygar bir hayat sürmek için kişinin maddesel kaygılardan uzak kalması gerekirken insanların iş yaşamına hazırlanmak için işten daha çok çalıştıkları dönem kariyer planlaması dönemidir. Bu dönem okul çağının her aşamasına girmiş, yoğunluklu olarak serbest zaman yoksunluğu üreten bir evredir. İnsanlar çoğunlukla kariyer planlaması için zamanlarının haz ve 
mutluluk veren bölümlerinden ödün vermektedirler. Kariyer planlaması yoğun bir çalışmayı gerektirdiğinden en kolay vaz geçilecek zaman dilimi kuşkusuz serbest zamanlardır (Kılıç 2019a).

Akademisyenler söz konusu olduğunda kariyer planlamasında yaşam boyu öğrenme ve üretme fikri gözden kaçırılmamalıdır. Akademisyenlerin sürekli yenilenme ve üretme fikri yaşamlarının her evresinde anlam bulurken, serbest zaman yoksunluğunun çoğunlukla plansız üretilmesinde "iş koliklik" ya da daha yumuşak bir tanımla "işe adanmak" söz konusudur. Kendini adama ya da mesleki adanmışlık diyerek kavramsallaştırabileceğimiz bu durum Stebbins'e göre (2016), kişilerin kendini geliştiren çalışmalara karşı güçlü bir adanmışlık ya da güçlü, pozitif bağımlılık hissettiklerinde gözlenir ve temel etkinlik yoğun bir çekicilik (kariyer planlama) sunduğundan, çalışma ve serbest zaman arasındaki çizgi adeta silinir.

Kendini adamak kişinin entelektüel sermayesini yaşam boyu arttırmak ve yenilemek için, bulunmaz bir şarttır. Kimileri için öğretim, kimileri içinde araştırma, merakı tatmin etme ve buluş yapma zevkini ve şerefini beraberinde getirmesidir (Rosovzky, 1996). Daha detaylı düşünüldüğünde profesyonel eğitim vermek, branşında günceli takip etmek, araştırma yapmak, bilimsel yayın-kitap yazmak, ulusal ve ulus ötesi toplantı ve sempozyumlara katılmak, danışmanlık yapmak, proje ve tezleri denetlemek, araştırmacılara yol göstermek, üniversitede akademik ve idari çalışmalara katılmak gibi belli bir zaman dilimine sığdırılamayacak birçok konu akademisyenlerin serbest zaman sınırlarını ortadan kaldırmada etkendir.

Serbest zaman aktivitelerine katılmak gibi bilim yapmakta insanlara haz ve mutluluk verir. Thomas Kuhn'un Bilimsel Devrimlerin Yapısı adlı kitabında bilimin çekiciliğini tanımlaması, kaya tırmanışının, yelken yapmanın, satrancın veya 
diğer serbest zaman aktivitelerinin ödüllerine benzer. Csikszentmihalyi'e (2018) göre de yüzlerce yıl boyunca mütevazı koşullar altında, fikirlerle oynamaya hayatını adamış insanların işlerini, bu onların bir mesleği olduğu ve yağlı devlet fonları olduğu için değil de, icat ettikleri yöntem onları büyülediğinden bir hobi olarak yaptıklarını ifadelendirmesi serbest zamanın hazzının akademisyenler tarafından yaptıkları bilimde anlamlandırılmasına kapı açmaktadır. Akademik bakış açısı hayatın her alanına o kadar sirayet etmiştir ki, üniversitelerin akademisyenlere sunduğu kampüs içi ve dışı rekreasyon olanaklarından yeterince faydalanmadıkları (Kılıç, 2013; 2016) görülmektedir.

\section{Yöntem}

Akademisyenlerin serbest zaman pratiklerini ve serbest zaman yoksunluklarını belirlemeyi amaçlayan bu araştırma nicel araştırma yöntemiyle tasarlanarak tesadüfi örneklem tekniğine göre 2019 yılında Düzce Üniversitesinde çalışan farklı akademik unvanlara sahip 422 kişiye anket uygulanarak tasarlanmıştır. 46 sorudan oluşan ankette bireylerin demografik özelliklerini, akademik kariyerlerini ve serbest zaman alışkanlıklarını tespite yönelik sorular yer almıştır. Sorular kapalı uçlu, açık uçlu ve yarı açık uçlu olarak hazırlanmış ve uygulama sonucunda araştırmacı tarafından standartlaştırılmıştır. Veriler SPSS programına yüklenerek analiz edilmiş; frekans dağılımı ve ki-kare analizleri yapılmıştır.

\section{Bulgular}

Araştırmaya katılan örneklemin \% 39,6'sı kadın ve \% 60,4'ü erkek akademisyenlerden oluşmaktadır. Kadınların \% 59,3'ü evli, \% 34,1'i bekâr ve \% 6,6'sı boşanmış, erkeklerin ise \% 81,1'i evli, \% 18,1'i bekâr ve \% 0,8'i boşanmış olarak tespit edilmiştir. Kadınların \% 3'ü Profesör, \% 7,9'u doçent, \% 30,5'i doktor öğretim üyesi, \%37,2'si öğretim görevlisi, \% 21,3'ü araştırma görevlisi unvanlarına sahipken erkeklerin \% 8,5'i profesör, \% 14,9'u doçent, \% 31,9'u 
doktor öğretim üyesi, \% 28,6'sı öğretim görevlisi ve \% 16,1'i araştırma görevlisi unvanlarına sahiptir. Cinsiyete bağlı olarak örneklemin hizmet yılı değerlendirildiğinde kadınların \% 44,6'sının 1-5 yıl arası, \% 35,5'inin 6-10 yıl arası, \% 10,2'sinin 11-15 yıl arası, \% 5,9' unun 16-20 yıl arası ve \% 4,2'sinin 21 yıl ve üstü akademi de çalıştıkları, erkeklerin ise \% 38,6'sının 1-5 yıl arası, \% 36,1'inin 6-10 yıl arası, \% 8,8'inin 11-15 yıl arası, \% 6,8'inin 16-20 yıl arası ve \% $9,6^{\prime} \operatorname{sının} 21$ yıl ve üstü akademide çalıştıkları tespit edilmiştir.

Evli kadınların \% 37,8' i 1-5 yıl arası ve \% 41,8'i 6-10 yıl arası akademide çalışırken evli erkeklerin \% 32,4'ü 1-5 yıl arası ve \% 39,2'si 6-10 yıl arası akademide çalışmaktadırlar. Örneklemin haftalık girilen toplam ders saatleri değerlendirildiğinde evli kadınların \% 32,6'sı haftada 13-20 saat arası, \% 30,2'si 21-30 saat arası ve \% 20,9' u 6-10 saat arası derse girerken evli erkeklerin \% $36,6^{\prime}$ sı $21-30$ saat arası, \% 26,9'u $13-20$ saat arası ve $\% 16,7^{\prime}$ si $31-40$ saat arası derse girmektedir. Bekâr kadınların \% 35,7'si 21-30 saat arası, \% 23,8'i 13-20 saat arası ve \% 19' u 31-40 saat arası derse girerken bekâr erkeklerin \% 26,7'si 13-20 saat arası, \% 23,3'ü 31-40 saat arası ve \% 20'si 6-12 saat arası derse girmektedir. Örneklemin akademik çalışmalarının yanında idari görevlerini de göz önünde bulundurduğumuzda evli kadınların \% 66,7'sinin (\% 37,5'i bölüm başkanı, \% 20,8', müdür yardımcısı ve \% 8,3'ü müdür) ve evli erkeklerin \% 65,1'inin (\% 40’ bölüm başkanı, \% 10’u müdür yardımcısı, \% 8,2'si dekan yardımcısı, \% 6,4'ü müdür ve \% 0,9'u dekan) idari görevleri olduğu tespit edilmiştir. Bekâr kadınların \% 33,3'ü bölüm bakanı, \% 16,7'si dekan yardımcısı, \% 5,6'sı dekan ve \% 5,6'sı müdür yardımcısı iken bekâr erkeklerin \% 30'u bölüm başkanı ve \% 30’u müdür yardımcısı idari görevlerini yürütmektedir. Yine boşanmış kadın akademisyenler bölüm başkanı ve boşanmış erkek akademisyenlerde müdür yardımcısı idari görevlerini yürütmektedirler. 
Akademisyenlerin “Serbest Zaman Yoksunluğuna” Etki Eden Unsurlar: Düzce Üniversitesi Örneği

Tablo 1. Cinsiyet bağlamında çalışma dışında örneklemin kendisine ayırdı̆ğ günlük ortalama serbest zaman

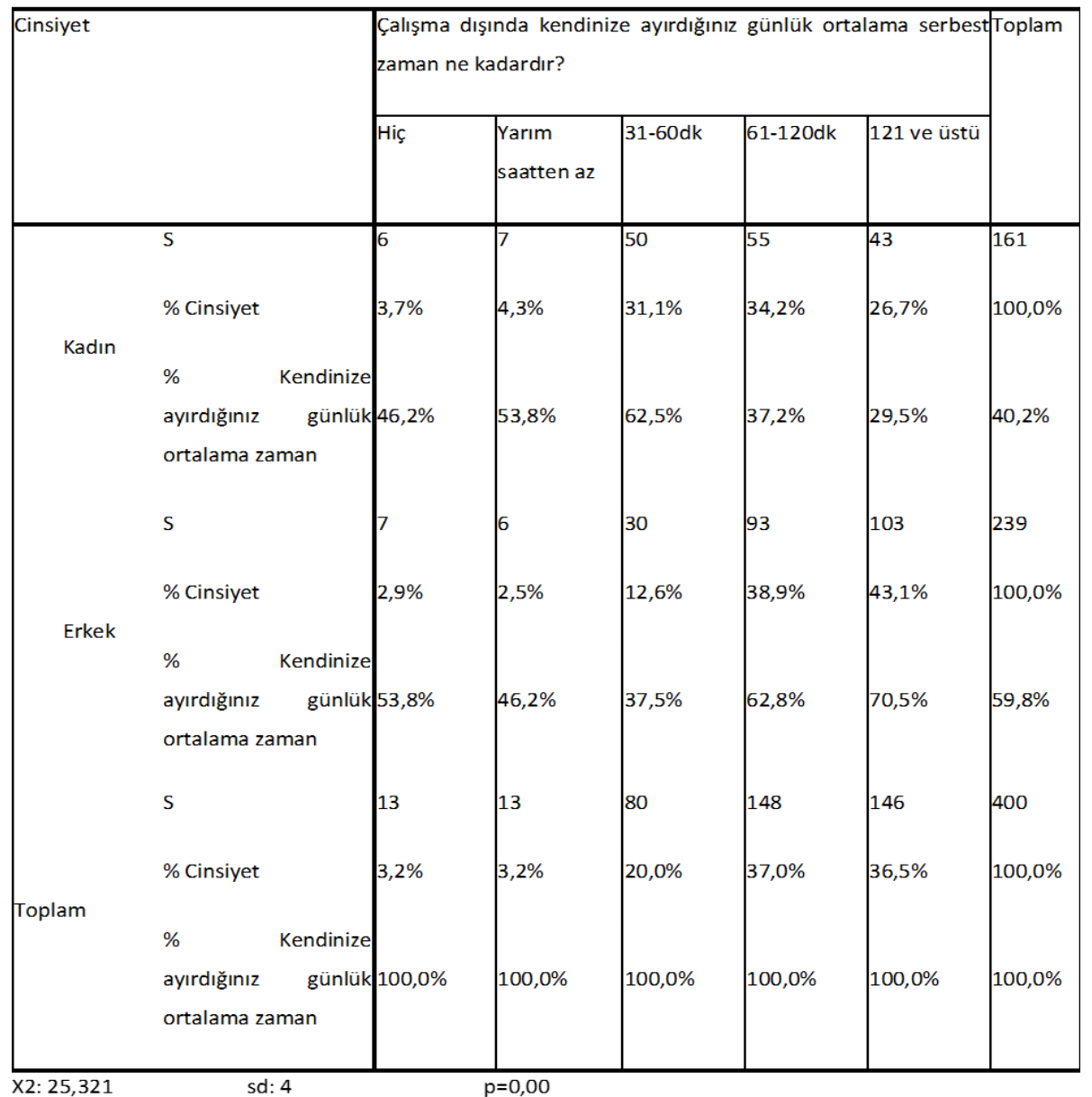

Tablo 1 de çalışma dışında örneklemin kendisine ayırdığı günlük ortalama serbest zaman tespit edilmeye çalışılmıştır. Kadınların \% 34,2'si 61-120 dakika arası, \% 31,1'i 31-60 dakika arası, \% 26,7'si 121 dakika ve üstü zaman ayırırken, erkeklerin \% 43,1'i 121 dakika ve üstü, \% 38,9’u 61-120 dakika arası, \% 12,6'sı 31-60 dakika arası kendisine zaman ayırdığını belirtmiştir. Yine kadınların \% 8'i ve erkeklerin \% 5,4'ü yarım saatten az ve hiç zaman ayırmadıklarını belirtmişlerdir. 
Evli olan kadınların \% 9,5'i yarım saatten az ve hiç, \% 42,8'i 31-60 dakika arası kendilerine zaman ayırdıklarını belirtirken, evli olan erkeklerin \% 6,2'si yarım saatten az ve hiç, \% 20,3'ü 31-60 dakika arası kendilerine zaman ayırdıklarını belirtmişlerdir. Evli kadınların \% 35,2'sinin ve evli erkeklerin \% 19,3'ünün çocuğu olmaması da göz önünde bulundurulduğunda çocuğu olan kadın ve erkeklerin çocuğu olmayan evli kadın ve erkeklere oranla kendilerine ayırdıkları zamanın daha da azaldığı tespit edilmiştir.

Bekâr kadınların ise \% 38,2'si 61-120 dakika arası, \% 32,7'si 121 dakika ve üstü, \% 21,8', 31-60 dakika arası kendilerine zaman ayırırken, bekâr erkeklerin \% 50'sini 121 dakika ve üstü, \% 40,9'unun 21-120 dakika arası kendilerine zaman ayırdığı tespit edilmiştir. Elde edilen veriler ışığında, serbest zaman yoksunluğu toplumsal cinsiyet bağlamında düşünüldüğünde, kadınların erkeklere oranla daha fazla serbest zaman yoksunluğu içerisinde olduğu söylenebilir (Kılıç, 2015, 2019). Yapılan araştırmalarda evli kadınlar kendilerine ayırabildikleri kısıtlı zamanda dahi erkeklere oranla daha az memnuniyet hissettikleri (Mattingly ve Bianchi, 2003) tespit edilmiştir. Bu memnuniyetsizlik kadınların serbest zamanlarındayken, yarım kalan işleri için endişe duymalarından, serbest zaman aktivitelerinde yalnızca kendi zevklerini değil diğer aile üyelerinin mutluluklarını da dikkate almalarından veya kendilerine zaman ayırmaları nedeniyle hissettikleri suçluluktan kaynaklanmaktadır. Kısacası, yetişkin bireylerin serbest zaman yoksunluğu ile toplumsal cinsiyet arasında yakın bir ilişki vardır (Mullahy ve Robert, 2008).

Araştırmaya katılan örneklemin günlük kendilerine ayırdıkları zamanı unvanlara göre incelediğimizde kendilerine hiç zaman ayıramadıklarını belirten kadınların $\%$ 66,7'sinin ve erkeklerin \% 42,9'nun doktor öğretim üyesi unvanına sahip olduğu tespit edilmiştir. Yine kendilerine hiç serbest zaman ayıramayan kadınların \% 33,3'ü ve erkeklerin \% 28,6'sı öğretim görevlisi/Dr unvanlarına sahiptir. 61-120 dakika ve üstünde kendilerine zaman ayırdıklarını belirten 
örneklem grubuna gelindiğinde çoğunlukla doçent ve profesör unvanlarında olan akademisyenler ön plana çıkmaktadır. Bu durum kariyer planlamanın serbest zaman yoksunluğu üzerine etkisini (Kılıç, 2019a) de ortaya çıkarmaktadır.

Tablo 2. Cinsiyet bağlamında serbest zamanları verimli geçirme(me) durumu

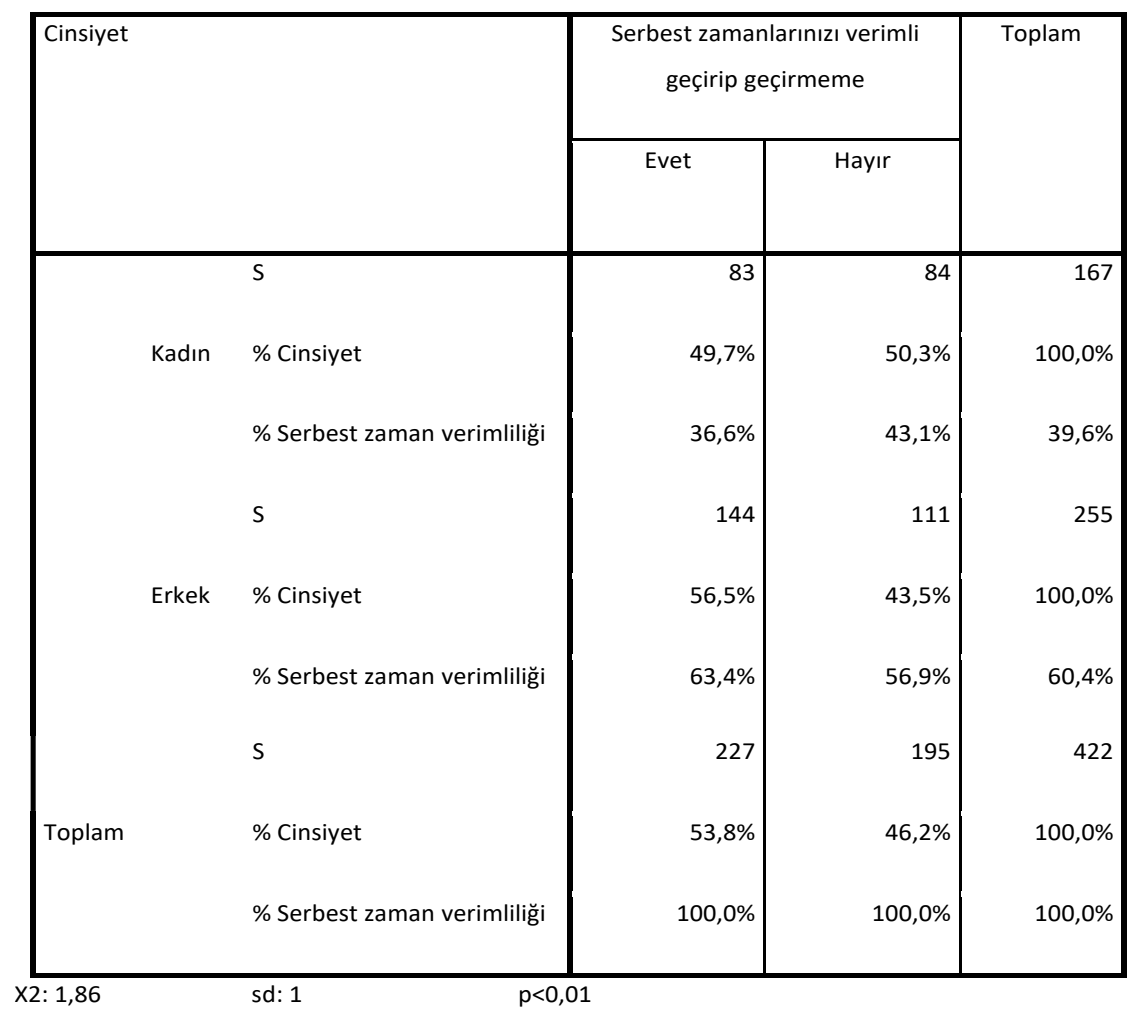

Örneklemin cinsiyet bağlamında serbest zamanlarını verimli geçirip geçirmeme durumları tablo 2 de tespit edilmeye çalışılmıştır. Cinsiyet göz önünde bulundurulduğunda kadın ve erkeklerin neredeyse yarısına yakını $(\% 46,2)$ serbest zamanlarını verimli geçiremediklerini belirtmiştir. $\mathrm{Bu}$ oran azımsanmayacak kadar yüksektir. Yine kadınlara oranla erkeklerin serbest 
zaman yoksunluğu biraz daha düşük seviyededir. Tablodan elde edilen veriler tablo 1'i destekler niteliktedir. Serbest zamanı verimli geçirme(me) durumu biraz daha detaylandırıldığında evli kadınların \% 49,9'u ve evli erkeklerin \% 42,2'si serbest zamanlarını verimli geçirmediklerini ifade etmişlerdir. Bekâr akademisyenler incelendiğinde kadınların \% 53,1'i ve bekâr erkeklerin \% 47,8'i serbest zamanlarını verimli geçirmediklerini ifade etmişlerdir.

Tablo 1 de akademisyenlerin unvanları gözetildiğinde serbest zaman olarak ayırdıkları zamanın unvanın artmasıyla orantılı arttığını tespit etmiştik. Serbest zamana ayrılan zamanın serbest zaman yoksunluğu çerçevesinde düşünüldüğünde bu zamanın verimli geçirileceği anlamına gelmemektedir (Kılıç, 2019a). Araştırmaya katılan kadın profesörlerin \% 80'inin ve erkek profesörlerin \% 57,1'inin serbest zamanlarını verimli geçirmemeleri ve doçent kadın örneklemin \% 33,3'ünün ve erkek doçentlerin \% 40,5'inin verimli geçirmedikleri tespit edilmiştir. Yine doktor öğretim üyesi kadınların \% 48'i ve erkek doktor öğreti üyelerinin \% 40,5'inin, öğretim görevlisi/öğretim görevlisi doktor kadınların \% 53,3'ü, erkeklerin \% 36,6'sı ve araştırma görevlisi kadınların \% 56,2'si ve erkeklerin \% 62'si serbest zamanlarını verimli geçirmediklerini belirtmişlerdir. Serbest zamanlarını verimli geçirmediklerini belirten akademisyenlerin daha çok meşgul oldukları serbest zaman aktivitelerini değerlendirmek gerekir. Akademisyenlerin en çok meşgul oldukları serbest zaman aktiviteleri aşağıda tablo 3'te verilmiştir. 
Akademisyenlerin “Serbest Zaman Yoksunluğuna” Etki Eden Unsurlar: Düzce Üniversitesi

Örneği

Tablo 3. Cinsiyet bağlamında akademisyenlerin ne tür serbest zaman etkinliklerine katıldıkları arasındaki ilişki

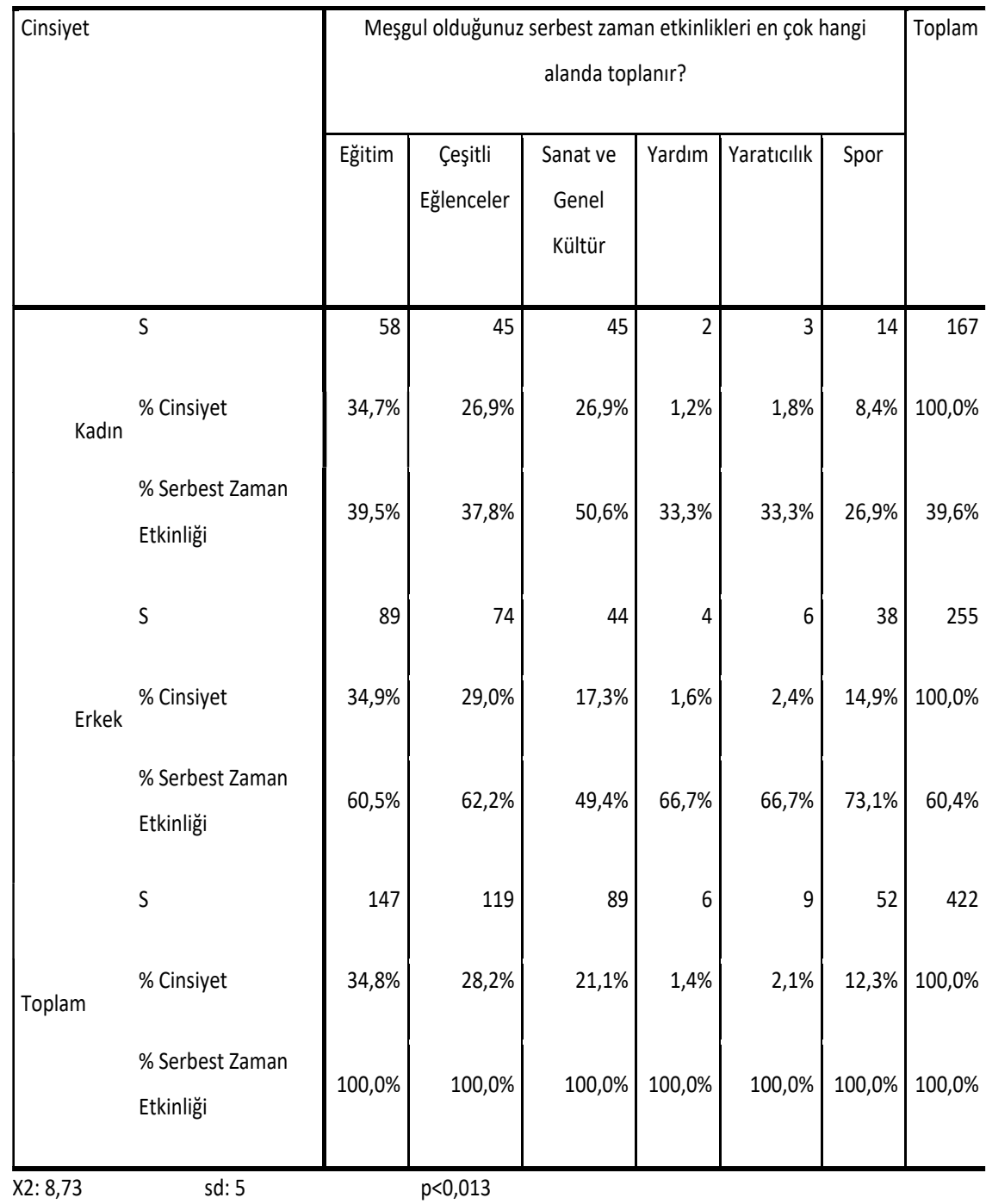

Akademisyenlerin cinsiyet bağlamında serbest zaman pratikleri değerlendirildiğinde araştırmaya katılan kadınların ve erkeklerin \% 34,8'inin "eğitim" ile ilgili serbest zaman aktivitelerine katıldıkları tespit edilmiştir. Bu 
durum esasında pasif serbest zaman olarak adlandıracağımız ve mesleği destekleyici, onun uzantısı olarak görülen aktivitelere yönelimi göstermektedir. Stebbins'in (2016) deyimiyle "kendini adamak", mesleki ve kariyere katkı yapan zamandan öte bir şeydir. Ve serbest zaman etkinliğinden ziyade serbest zaman yoksunluğunu besleyen bir paradigmadır. Tablo 2'de örneklemin serbest zamanlarını verimli geçirmediğinin yoğun bir şekilde tespit edilmesinin arkasında yatan sebeplerden birisi de kendini adamakla ilgilidir.

Eğitim dışında kadın akademisyenlerin \% 26,9'u "çeşitli eğlenceler", \% 26,9'u "sanat ve genel kültür" ile ilgili aktivitelere katılırken, erkek akademisyenlerin \%29'u "çeşitli eğlenceler", \% 17,3'ü "sanat ve genel kültür" ile ilgili aktivitelere katılmaktadırlar. Akademisyenlerin cinsiyet farkı gözetmeksizin kişide serbest zaman doyumu ve tatmin duygusu yaratacak olan "yardım" ve "yaratıcılık" gibi etkinliklere katılım oranlarının oldukça düşük olması da serbest zaman yoksunluğunu desteklemektedir. Yardım ve yaratıcılığa oranla daha yüksek katılımın olduğu spor etkinlikleri serbest zaman için oldukça önemlidir. Spencer’ın 1896 yılında yazdığı Psikolojinin Prensipleri adlı önemli eserinde sportif aktivitelerin insanın gerilimini düşürdüğü ve kişiye olumlu katkı sağladığından, gün boyu fiziksel çaba gerektiren bir işte çalışan bireylerin zihinsel etkinliklerle, gün boyu zihinsel çaba gerektiren bir işte çalışan bireylerinde fiziksel etkinliklerle meşgul olmasının faydalı olacağı (Kılıç, 2019b) gözetildiğinde zihinsel açıdan yoğun çalışan kadın akademisyenlerin sadece \% 8,4'ünün ve erkek akademisyenlerin \% 14,9'unun sportif aktivitelere katılması akademisyenler açısından serbest zamanların pozitif faydasını azaltmakta ve serbest zaman yoksunluğunu desteklemektedir. Yine medeni durum gözetildiğinde evli -bekâr, kadın ya da erkek arasında belirgin bir farklılık bulunmamaktadır. Medeni durumla ilgili aktivitelere (eğitim, çeşitli eğlence, sanat ve genel kültür) katılım oranları benzerdir. 
Tablo 4. Örneklemin serbest zamanlarını değerlendirme biçimleri arasındaki anlamlı ilişki

\begin{tabular}{|l|l}
\hline \multicolumn{1}{|c|}{ Etkinlik Türleri } & \multicolumn{1}{c}{ Ki-kare analizi } \\
\hline Hiçbir şeyle uğraşmam dinlenirim & 0,761 \\
\hline Kitap, gazete, dergi okurum & $\mathbf{0 , 0 0 2}$ \\
\hline Tv izlerim & 0,262 \\
\hline Sinema ve tiyatroya giderim & 0,074 \\
\hline Sosyal ve kültürel faaliyetlere katılırım (sergi, konferans, toplantı, söyleşi) & $\mathbf{0 , 0 2 9}$ \\
\hline Spor yaparım & 0,739 \\
\hline Çarşı Pazar gezerim, alışveriş yaparım & 0,857 \\
\hline Ailem ve çocuklarımla ilgilenirim & $\mathbf{0 , 0 2 7}$ \\
\hline Arkadaşlarla sohbet ederim/gezerim & 0,155 \\
\hline Internetten yararlanırım (oyun vb) & 0,214 \\
\hline Komşularıma veya akrabalarıma giderim & 0,355 \\
\hline Hobilerimle ilgilenirim & 0,115 \\
\hline
\end{tabular}

Tablo 4'te ki-kare analizine göre elde edilen veriler tablo 3'ü destekler niteliktedir. Tablo 4'te anlamlı sonuçlar göz önünde bulundurulduğunda cinsiyet farkı gözetmeksizin örneklemin "kitap, gazete, dergi okurum”, "Sosyal ve kültürel faaliyetlere katılırım (sergi, konferans, toplantı, söyleşi)", "Ailem ve çocuklarımla ilgilenirim" cevaplarını vermesi serbest zamanlarını daha çok işin uzantısı olarak kullandıklarını göstermektedir. Şöyle ki bu iddiayı desteklemek adına "Serbest zaman aktivitelerinin sağlığınızı olumlu etkilediğini düşünüyor musunuz?" sorusuna kadınların \% 94,6'sı ve erkeklerin ,\% 91,3 evet cevabını vermiştir. Yine "Serbest zaman aktivitelerine ayırabileceğiniz zamanın daha fazla olmasını ister miydiniz? Sorusuna kadınların \% 89,9'u ve erkeklerin \% 87,7'si evet cevabını vermiştir. O halde daha fazla serbest zamanları olması durumunda yine benzer işi destekleyici faaliyetler içinde bulunacakları ve bu faaliyetlere 
ayrılan zamanın yeterli olmadığı görülmektedir. Bu sonuçlar çerçevesinde serbest zamanın üretilmeden tüketilmesi yani serbest zaman yoksunluğunun artması söz konusudur.

\section{Sonuç}

Serbest zamanın günümüzde kullanım şekilleri oldukça çeşitlilik göstermektedir. Kimilerine göre sağık, sosyalleşme, kendini gerçekleştirme imkânı sağlayan zaman olarak anlamlandırılırken, kimilerine göre de dinlenme, eğlenme ya da ulaşılması zor bir zaman olarak anlamlandırılmaktadır. Gündelik yaşamda en çok ihtiyaç duyulan böylesine değerli bir zamanın sosyal sınıf bağlamında kullanım şekilleri de değişiklik göstermektedir. Akademisyenlerin sınıfsal özellikleri gözetildiğinde belki de en çok düşünülen ve üzerine yeterince çalışma yapılmayan alanlardan birisi serbest zaman pratikleridir. Çünkü akademisyenlik üzerindeki genel geçer algıların başında kuşkusuz mesai kavramından öte gecegündüz sürekli çalıştıkları üzerinedir. Bu açıdan bu çalışmada serbest zaman yoksunluğu kavramından yola çıkarak akademisyenlerin serbest zamanlarını nasıl ürettiklerinden ziyade nasıl tükettikleri argümanını sorgulama çabasındadır. Akademisyenlerin günlük kendilerine ayırdıkları serbest zamanlarını incelediğimizde serbest zaman tüketimini görmek mümkündür. Çünkü araştırmaya katılan akademisyenlerinin bazılarının günlük hiç serbest zamanlarının olmadığını belirtmelerinin yanında ciddi bir oranının 1 saatten az kendilerine zaman ayırabilmeleri serbest zaman yoksunluğunun niceliksel göstergesidir. Yine cinsiyet bağlamında düşünüldüğünde kadınların-erkeklere oranla serbest zamanlarının daha az olduğu tespit edilmiştir. Bu tespit sınıfsal yapıları aşan ve toplumsal açıdan düşünülmesi gereken bir realitedir. Yapılan çalışmalarda farklı toplumlarda kadınların erkeklere oranla daha az serbest zamanlarının olduğu (Shaw, 1994; Sayer, 2005; Mattingly ve Bianchi, 2003) tespit edilmiştir. 
Araştırmada serbest zaman yoksunluğunu destekleyen en önemli göstergelerden birisi kuşkusuz kariyer planlamasıdır. Akademisyenlik mesleğinin sürekli kendini yenilediği ve bir üst aşamaya geçebilme çabasının güdüldüğü bir meslek olması açısından sürekli çalışmayı önceleyen bir bakışa kapı açması söz konusudur. Bu açıdan düşünüldüğünde unvanlara bağlı olarak kendilerine hiç serbest zaman ayıramadıklarını belirten kadınların \% 66,7'sinin ve erkeklerin \% 42,9'nun doktor öğretim üyesi unvanına sahip olduğu tespit edilmiştir. Yine kendilerine hiç serbest zaman ayıramayan kadınların \% 33,3'ü ve erkeklerin \% 28,6'sı öğretim görevlisi/Dr unvanlarına sahiptir. Bu unvanlar göz önünde bulundurulduğunda bir üst aşamaya geçme istenci diğer akademik unvanlara göre daha yüksektir. Ve bu tür akademik unvanlar serbest zaman yoksunluğunu kariyer planlaması bağlamında üretmektedir. Akademik unvanlar yükseldikçe (doçent-profesör) serbest zamanın niceliksel oranı artması söz konusuyken, serbest zaman pratikleri değerlendirildiğinde unvan ve cinsiyet farkı gözetmeksizin akademisyenlerin çoğunlukla eğitim, sanatsal kültürel faaliyetler içerisinde yer aldığı tespit edilmiştir. Bu serbest zaman pratiklerinin akademisyenlik mesleğini destekleyen serbest zaman pratikleri olması da gözden kaçırılmaması gereken bir durumdur. O halde akademisyenlerin işin devamı niteliğindeki yani işi destekleyen etkinliklere yönelmesi serbest zamanının kişiye kazandırdığı birçok pozitif etkiden yoksun kalmalarında etkendir. Bu durum somut bağlamda serbest zaman yoksunluğunu ortaya çıkarmaktadır. Şöyle ki, kariyer planlaması için serbest zamana ayıracak zamanları olmayan ara unvanlardaki akademisyenlerle en üst akademik unvanlara sahip olan akademisyenlerin serbest zaman pratiklerinin aynı olması "yardım", "yaratıcılık" gibi kişilerde tatmin duygusu oluşturacak etkinliklerden ziyade "eğitim", "kültürel, "sanatsal" gibi akademisyenlerde haz ve mutluluk duygusu yaratacak etkinlikler içerisinde yer alınması, serbest zaman türünün de akademisyenler için uzun vadede değişmesi zor ve sınırlı bir alanda var olması 
anlamına gelmektedir. İçeriği oldukça geniş olan serbest zaman aktivitelerinin bu şekilde sınırlandırılması da akademisyenler tarafından serbest zaman yoksunluğunun yeniden üretilmesine imkân sağlamaktadır. Çünkü serbest zaman aktivitelerinin sınırlandırılması, belli etkinliklerin dışına uzun vadede çıkılmaması da serbest zaman yoksunluğudur.

Son olarak akademisyenler serbest zamanın önemli bir zaman olduğunu ve daha fazla serbest zamanlarının olması gerektiğini belirtmeleri söz konusudur. Değerli zaman olarak atfettiğimiz serbest zamanı üreten ve tüketen kuşkusuz kişinin kendisidir. Bu açıdan düşünüldüğünde akademisyenler bu değerli zamanın farkındadırlar ama daha fazla serbest zaman elde ettiklerinde (elde edilen verilerden hareketle) bu zamanların büyük bir çoğunluğunu yine standartlaşan ve işin devamı niteliğindeki serbest zaman aktivitelerine harcanmaları serbest zaman yoksunluğunu yeniden üretir. 


\section{Kaynakça}

BAUMAN, Z. (2012). Küreselleşme: Toplumsal Sonuçları, 4. Basım, (Çev. Abdullah Yılmaz), İstanbul: Ayrıntı Yayınları.

BOURDiEU, P. (2016). Akademik Aklın Eleştirisi Pascalca Düşünme Çabaları, Çev. P. Burcu Yalım, 2. Basım, İstanbul: Metis Yayınları.

CSikSZENTMihalyi, M. (2018). Akış: Mutluluk Bilimi, (Çev. Esra E. Orhan), 3. Basım, Ankara: Buzdağı Yayınevi.

KILIÇ, M. ve ŞENER, G. (2013), Üniversite Öğrencilerinin Rekreasyon Etkinliklerine Katılımlarındaki Sosyolojik Etkenler ve Yapısal Kısıtlamalar, Journal of Higher Education \& Science/Yükseköğretim ve Bilim Dergisi, 3(3): 220-227. KILIÇ, M. (2015). Aile ve Serbest Zaman İlişkisi Düzce Örneği, Düzce Üniversitesi Sosyal Bilimler Enstitüsü Dergisi, 5(1): 27-49.

KILIÇ, M. (2019a). Leisure Time Deprivation, Modern Leisure Studies, 1(1): 1-12

KILIÇ, M. (2019b), Suç ve Eğlence, Psiko Sosyal Yönleriyle Eğlence(iç), s:227-249, (Edt. Metin Kılıç), Ankara: Nobel Akademik Yayıncılık.

KILIÇ, M. (2020). Sapkın Serbest Zaman, Modern Leisure Studies, 2(1): 1-10

KiLiC, M. (2016). Leisure Time Use of University Youth within the Campus: Duzce Example, 5th Annual International Conference on Humanities and Social Sciences, 22-25 September, Budapest, Hungary, pp: 328-333.

MACCANNELL, D. (1999). The tourist: a new theory of the leisure class. Los Angeles: University of California.

MATTINGLY, M. J. ve Bianchi, S. M. (2003). Gender differences in quantity and quality of free time: The U.S. experience. Social Forces, 81: 999-1030. 
MULLAHY, J. ve ROBERT, S. A. (2008). No time to lose?Time constraints and physical activity. Cambridge, MA.

ÖZTÜRK, E. (2019). Serbest Zaman ve Eğlence: Serbest Zaman ve Eğlence İlişkisi Üzerine Holistik Bir Yaklaşım, Psiko Sosyal Yönleriyle Eğlence(iç), s:13-62, (Edt. Metin Kılıç), Ankara: Nobel Akademik Yayıncılık.

PATERSON, M. (2006). Consumption and everyday life. London and New York: Routledge.

ROSOVSKY, H. (1996). Üniversite Bir Dekan Anlatıyor, (Çev. Süreyya Ersoy) 9. Basım, Ankara: TÜBiTAK Popüler Bilim Kitapları.

SAYER, L.C. (2005). Gender, time, and inequality: Trends in women's and men's paid work, unpaid work, and free time. Social Forces, 84:285-303.

SHAW, S. M. (1994). Gender, Leisure, and Constraint: Towards a Framework for the Analysis of Women's Leisure. Journal of Leisure Research, 26(1):8-22.

STEBBiNS, A.R. (2016). Serbest Zaman Fikri Temel illkeler, (Çev. Mehmet Demirel, Nurullah E. Ekinci, Ümit D. Üstün, Utku Işık, Osman Gümüşgül), Ankara: Spor Yayınevi ve Kitabevi.

OLGUN, K. C. (2019), Statü ve Eğlence, Psiko Sosyal Yönleriyle Eğlence(iç), s:137166, (Edt. Metin Kılıç), Ankara: Nobel Akademik Yayıncılık. 


\section{Extended Summary}

Today, how leisure time is used vary considerably. According to some, it is understood as a time that provides the opportunity for health, socialization and self-realization. In contrast, there are others interpreted as a time of rest, fun or hard to reach. The use of such valuable time, which is most needed in daily life, also varies in social class. Considering the class characteristics of academics, one of the areas considered the most and not studied enough may be leisure time practices because one of the common perceptions on academics would be that they work day and night beyond working hours. In this respect, this study attempts to question the argument that academics consume their leisure time rather than how they produce it, based on the concept of leisure time deprivation. It is possible to see leisure time consumption when we examine the time that academics allocate for themselves daily. Because some of the academics who participated in the research stated that they have no daily leisure time, and the fact that a significant proportion of them could spare less than 1 hour for themselves would be a quantitative indicator of leisure time deprivation. Considering gender differences, it was reported that women had less leisure time than men. This finding may be a reality beyond class structures, and it needs to be considered socially. Studies presented that women in different societies had less leisure time than men (Shaw, 1994; Sayer, 2005; Mattingly \& Bianchi, 2003).

Without a doubt, one of the most important indicators supporting leisure time deprivation in the research would be career planning. Since the academic career is a profession that constantly renews itself and strives to move to the next level, it opens the door to a perspective that prioritizes continuous work. From this point of view, it was found that $66.7 \%$ of the women and $42.9 \%$ of the men, who stated that they could not spare any leisure time depending on their 
titles, had the title of assistant professor. Similarly, $33.3 \%$ of women and $28.6 \%$ of men, who could not spare any leisure time for themselves, hold lecturer/Dr titles. Considering these titles, the desire to move to the next level was higher than other academic titles. And such academic titles would produce a leisure time deprivation in the context of career planning. While the quantitative ratio of leisure time increased, academic titles were also promoted (associate professor-professor). When leisure time practices were evaluated, academics were mostly involved in education, artistic and cultural activities, regardless of title and gender. It should be noticed that these practices were leisure time activities that could support the academic profession. In that case, the fact that academics tended to activities that were a continuation of the work, that is, supporting the work, could be a factor in their deprivation of many positive effects of leisure time. This situation reveals leisure time deprivation in a concrete context. Namely, there was a reality that the leisure practices of the academics with intermediate titles who do not have time to spare for career planning and those who hold the highest academic titles were the same. This would lead to taking part in activities that would create a sense of pleasure and happiness in academics such as "education," "cultural," and "artistic" rather than activities that would create a sense of satisfaction in people such as "help" and "creativity" resulting in the existence of leisure time in a restricted area that can be difficult for academics to change in long-term. Such restrictions in leisure time activities, which have a very wide content, also led academics to reproduce leisure time deprivation because restricting leisure time activities and the inability to stay out of certain activities in the long term may also be leisure time deprivation.

Finally, academics reported that leisure time is an important time and needed to have more. Undoubtedly, it is the person himself who could produce and consume leisure time that we attribute as valuable time. From this perspective, 
Akademisyenlerin “Serbest Zaman Yoksunluğuna" Etki Eden Unsurlar: Düzce Üniversitesi Örneği

academics were aware of this valuable time, but when they have more leisure time (based on the data obtained), spending most of this time on leisure activities that were also standardized and continuation of work would reproduce leisure time deprivation. 